\title{
OPTIMALISASI PEMANFAATAN WADUK TILONG, NUSA TENGGARA TIMUR UNTUK PENGEMBANGAN PERIKANAN TANGKAP
}

\section{OPTIMIZATION UTILIZATION OF TILONG RESERVOIR, KUPANG DISTRICT, EAST NUSA TENGGARA FOR CAPTURE FIHERIES DEVELOPMENT}

\author{
Andri Warsa $^{1)^{*}}$ Joni Haryadi1) Endi Setiadi Kartamihardja ${ }^{2)}$ \\ 1)Balai Penelitian Pemulihan dan Konservasi Sumberdaya ikan \\ Jalan Cilalawi No 1 Jatiluhur Purwakarta, 41152, Jawa Barat, Indonesia \\ 2)Pusat Penelitian Pengembangan Kelautan dan Perikanan \\ Jalan Pasir Putih II, Ancol Timur, 14430 Jakarta Utara, Indonesia \\ *Coresponden author: andriwarsa@yahoo.co.od \\ Diterima: 30 April 2018; Direvisi: 10 Oktober 2018; Disetujui: 22 Mei 2019
}

\begin{abstract}
The Tilong Reservoir located in Kupang District, has 154.97 ha surface area with an average depth of $12.5 \mathrm{~m}$, water volume is 19 million $\mathrm{m}^{3}$ and water discharge around 86.4-106.3 $\mathrm{m}^{3} /$ day. The main function of this reservoir is for irrigation. Capture fisheries activity has not been optimally developed. The development of capture fisheries can be done through culture-based fisheries (CBF), namely milkfish (Channos channos) or tilapia (Oreochromis niloticus) stocking. The aims of this study is to determine the potential of fisheries production and the seed needs for CBF development in the Tilong reservoir. The study was conducted in March and September 2016 at three observation stations. Water sample was taken at 0.5 and $2.0 \mathrm{~m}$ from the surface which is the euphotic depth. The results showed that CBF activities in the Tilong Reservoir could successful because supported by the limnology conditions was suitable for fish life, the availability of seeds produced from hatchery was sufficient for stocking and support of local communities through local wisdom. Fish seeds are produced by 13 hatchery which are capable of producing milkfish and tilapia seeds of 7,040,770 and 7,023,400 per year. Based on these aspects, capture fisheries through CBF are feasible to be developed in the Tilong Reservoir. The fisheries production potential in the Tilong Reservoir ranges from 75.9 to $77.5 \mathrm{~kg} / \mathrm{ha} /$ year or 11.9-12.0 tons/year. The optimal number of milkfish and tilapia seeds that can be stocked ranges from 71,000-73,500 individuals/year and 72,000-75,000 individuals/year respectively. The fish production estimated from stocking was about $40 \%$ of the potential production with economic value of $R p 20,500,000$ and $R p 21,500,000$.
\end{abstract}

Keywords: Tilong Reservoir, production potential, culture-based fisheries

\section{ABSTRAK}

Waduk Tilong yang terletak di Kabupaten Kupang mempunyai luas genangan 154,97 ha dan kedalaman rata-rata 12,5 $\mathrm{m}$ dengan volume air 19 juta $\mathrm{m}^{3}$ serta debit air keluar berkisar antara 86,4-106,3 $\mathrm{m}^{3} /$ hari. Fungsi utama waduk ini adalah sebagai sumber air irigasi. Kegiatan perikanan tangkap belum dikembangkan secara optimal di waduk ini. Pengembangan perikanan tangkap dapat dilakukan melalui perikanan berbasis budidaya (Culture-based fisheries, CBF) yaitu dengan penebaran ikan bandeng (Channos channos) atau nila (Oreochromis niloticus). Penelitian ini bertujuan untuk mengetahui potensi produksi perikanan dan kebutuhan benih untuk pengembangan CBF di waduk Tilong. Penelitian dilakukan pada bulan Maret dan September 2016 pada tiga stasiun pengamatan. Pengambilan contoh air dilakukan pada kedalaman 0,5 dan 2,0 m dari permukaan yang merupakan kedalaman eufotik. Hasil penelitian menunjukkan bahwa kegiatan CBF di waduk Tilong dapat berhasil karena didukung oleh kondisi limnologi layak untuk kehidupan ikan, ketersediaan benih yang dihasilkan oleh balai benih ikan (BBI) mencukupi untuk penebaran dan juga adanya dukungan masyarakat sekitar melalui kelembagaan adat. Benih ikan bandeng dan nila yang dihasilkan oleh 13 BBI masing-masing sebanyak 7.040.770 dan 7.023.400 ekor/tahun. Ditinjau dari aspek kualitas air, ketersediaan benih dan juga nilai ekonomi yang diperoleh maka perikanan tangkap melalui CBF layak dikembangkan di waduk Tilong. Potensi produksi perikanan di waduk Tilong berkisar 75,9-77,5 kg/ha/tahun atau sebesar 11,9-12,0 ton/tahun. Jumlah benih optimal ikan bandeng dan nila yang dapat ditebar masing-masing berkisar 71.000-73.500 ekor/tahun dan 72.000-75.000 ekor/tahun. Estimasi produksi ikan tangkapan dari kegiatan penebaran ini sekitar 40\% dari potensi produksi perairan dengan nilai ekonomi sebesar Rp 20.500.000 dan $\mathrm{Rp} 21.500 .000$.

Kata kunci: Waduk Tilong, potensi produksi, perikanan berbasis budidaya 


\section{PENDAHLUAN}

Di Provinsi Nusa Tenggara Timur (NTT) terdapat sebanyak 963 embung dan 3 waduk yang salah satunya adalah waduk Tilong. Kegiatan perikanan tangkap belum berkembang baik di waduk Tilong. Aktivitas perikanan yang ada hanya kegiatan pemancingan sebagai hobi sehingga produksi perikanan belum optimal. Salah satu upaya yang dapat dilakukan untuk pengembangan perikanan di waduk Tilong adalah dengan pengembangan perikanan berbasis budiaya (CBF, Cultre-Based Fisheries). Kegiatan perikanan dengan CBF ini merupakan suatu upaya penyedia protein hewani berasal dari ikan yang sangat dibutuhkan oleh masyarakat dan harganya juga cukup terjangkau. Kebutuhan ikan bandeng untuk memenuhi kebutuhan pasar di kota Kupang masih sangat tinggi dan dipenuhi dengan mendatangkan ikan dari Makasar (Prianto dkk., 2017). Peningkatan produksi ikan dengan penebaran ikan umum dilakukan di beberapa badan air di Cina (Wang dkk., 2015; Li, 1999), Sri Lanka (Jayasinghe dkk., 2006), Kamboja (De Silva dan Song, 2015), Vietnam (Phan dan De Silva, 2000) dan Indonesia (Kartamihardja, 2012). Kegiatan penebaran ikan dalam rangka peningkatan produksi perikanan tangkap di beberapa badan air di Indonesia antara lain penebaran ikan bilih (Mystaecoleucus padangensis) di Danau Toba (Umar dan Kartamihardja 2011), patin (Pangasianodon Hypophthalmus) di Wonogiri (Kartamihardja dan Purnomo, 2005), nila (Oreochromis niloticus) di waduk Malahayu (Purnomo, 2011) serta bandeng (Channos channos) di waduk Jatiluhur (Tjahjo dan Purnamaningtyas, 2008a).

CBF merupakan suatu teknik penting untuk peningkatan produksi perikanan terutama di negara berkembang. Kelebihan CBF dari kegiatan budidaya tradisional adalah tidak diperlukan badan air yang besar dan bukan merupakan pengggguna sumberdaya air primer sehingga tidak mengganngu pemanfaatan lainnya (De Silva, 2003). Upaya yang dapat dilakukan untuk pemacuan sumberdaya ikan pada perairan umum daratan adalah dengan melakukan penebaran (Moreau dan De Silva 1991) dan penyuburan perairan untuk peningkatan produktivitas perairan (Kartamihardja dkk., 2009). Perikanan tangkap di perairan umum daratan di beberapa badan air di NTT belum berkembang. Upaya penebaran ikan nila yang pernah dilakukan belum memberikan hasil yang optimal dalam peningkatan produksi, karena kurangnya kajian ilmiah sebelum melakukan penebaran. Penebaran ikan dalam program perikanan CBF kurang mempertimbangkan faktor daya dukung lingkungannya (carrying capacity). Padahal potensi produksi perikanan CBF sangat tergantung dari produktivitas ekosistem perairannya (Lorenzen dkk., 2001). Tujuan penelitian adalah untuk mengetahui potensi perikanan dan pengembangan perikanan berbasis budidaya di waduk Tilong.

Bendungan Tilong mulai dibangun tahun 1999 dan selesai tahun 2001. Waduk Tilong yang terletak di Kabupaten Kupang (Gambar 1) mempunyai luas genangan sebesar 154,97 ha dengan volume 19 juta $\mathrm{m}^{3}$ dengan kedalaman ratarata $12,5 \mathrm{~m}$. Fungsi utama pembangunan waduk ini adalah sebagai sumber air irigasi sawah seluas 1484 ha (Ludiana dkk., 2015). Luas daerah tangkapan air (DTA) waduk Tilong seluas 4.949 ha dengan debit air keluar (outflow) bekisar 86,4106,3 $\mathrm{m}^{3}$ /hari (Tampani dkk., 2016). Laju sedimentasi sebesar 25.428 ton/tahun (Fallo dkk., 2013). DTA di waduk Tilong didominasi oleh semak belukar dan lahan pertanian (Ahab dkk., 2016).

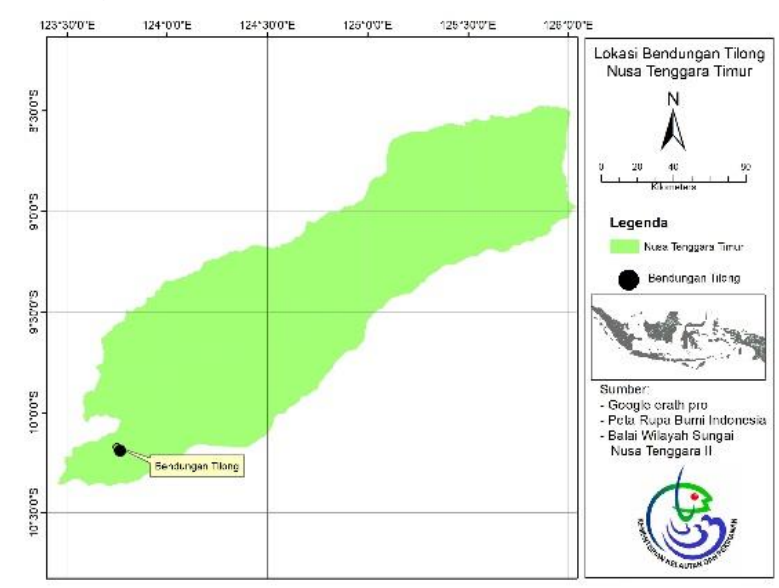

Gambar 1 Lokasi Waduk Tilong di NTT

Perikanan berbasis budidaya (culture-based fisheries, CBF) adalah perikanan tangkap yang kebanyakan atau seluruhnya bergantung pada input benih dari luar atau panti benih (FAO, 1997). Pengembangan CBF, baik yang berupa penebaran maupun introduksi berbagai jenis ikan sudah sering dilakukan di berbagai perairan umum daratan Indonesia. Perikanan CBF biasanya dilakukan di perairan yang berukuran relatif kecil (De Silva dan Funge-Smith, 2005). Nguyen dkk. (2001) berdasarkan pengalaman peneltiannya di sejumlah waduk dan danau tapal kuda (oxbow lakes) di Vietnam yang kurang dari 200 ha. Pengembangan $\mathrm{CBF}$ di peraian musiman telah banyak dilakukan di Sri Lanka dengan hasil yang berkisar antara 53,3 - $1800 \mathrm{~kg} / \mathrm{ha}$ (Wijenayake dkk., 2005).

\section{METODOLOGI}

Pengambilan contoh air dilakukan pada bulan Maret dan September yang diharapkan 
untuk mewakili musim hujan dan kemarau. Data curah hujan menunjukkan bahwa pada bulan maret berkisar antara 52-186 $\mathrm{mm} /$ bulan dengan rata-rata $111 \mathrm{~mm} /$ bulan dan pada bulan September berkisar antara 0-13 mm/bulan dengan rata-rata 2,9 mm/bulan (Tampani dkk., 2016). Pengambilan contoh air pada kedalaman 0,5 m dan $2 \mathrm{~m}$ dari permukaan untuk mewakili zona eufotik yang dihitung berdasarkan nilai kecerahan (An dan Jones, 2000) yaitu 2,3-3,0 m.

\section{Waktu dan lokasi penelitian}

Penelitian di lakukan di waduk Tilong pada bulan Maret dan September 2016. Pengambilan contoh air dilakukan dengan menggunakan Kemmerer Water Sampler pada kedalaman 0,5 m (dari permukaan) dan $2 \mathrm{~m}$. Pengamatan kualitas air dilakukan baik secara insitu maupun eksitu. Pengambilan contoh air dilakukan pada tiga lokasi (Gambar 2). Parameter kualitas air dan metode/alat yang digunakan di sajikan pada tabel 1.

Untuk mengetahui kondisi sosial kelembagaan masyarakat dilakukan wawancara dengan 15 responden terpilih dengan metode Purposive Sampling Methods (Palys, 2008). Responden terpilih merupakan masyarakat yang berdomisili di sekitar perairan. Wawancara dilakukan dengan menggunakan bantuan kuisioner. Data yang diperoleh kemudian dianalisis secara diskriptif. Data sekunder berupa produksi benih ikan diperoleh dari Dinas Kelautan dan Perikanan NTT dan data aspek biologi calon ikan tebaran diperoleh dari penelusuran pustaka.

\section{Analisis Data}

Potensi produksi ikan di suatu badan air ditentukan oleh morfologi yaitu luas badan air dan kedalaman rata-rata, nutrien, padatan total terlarut, daya hantar listrik, klorofil-a dan produktivitas primer perairan (Mustapha, 2009; Gomes dkk, 2002; Averhoff, 1999). Produktivitas primer ditentukan oleh beban masukkan nutrien dari daerah tangkapan air serta morfohidrologi badan air (Dillon dan Rigler, 1975). Jumlah ikan yang dapat ditebar di suatu badan air ditentukan oleh potensi perikanan serta luasan badan air (Quiros, 1999) sedangkan produksi ikan tebaran ditentukan oleh jumlah ikan yang ditebar (Nguyen dkk., 2001).

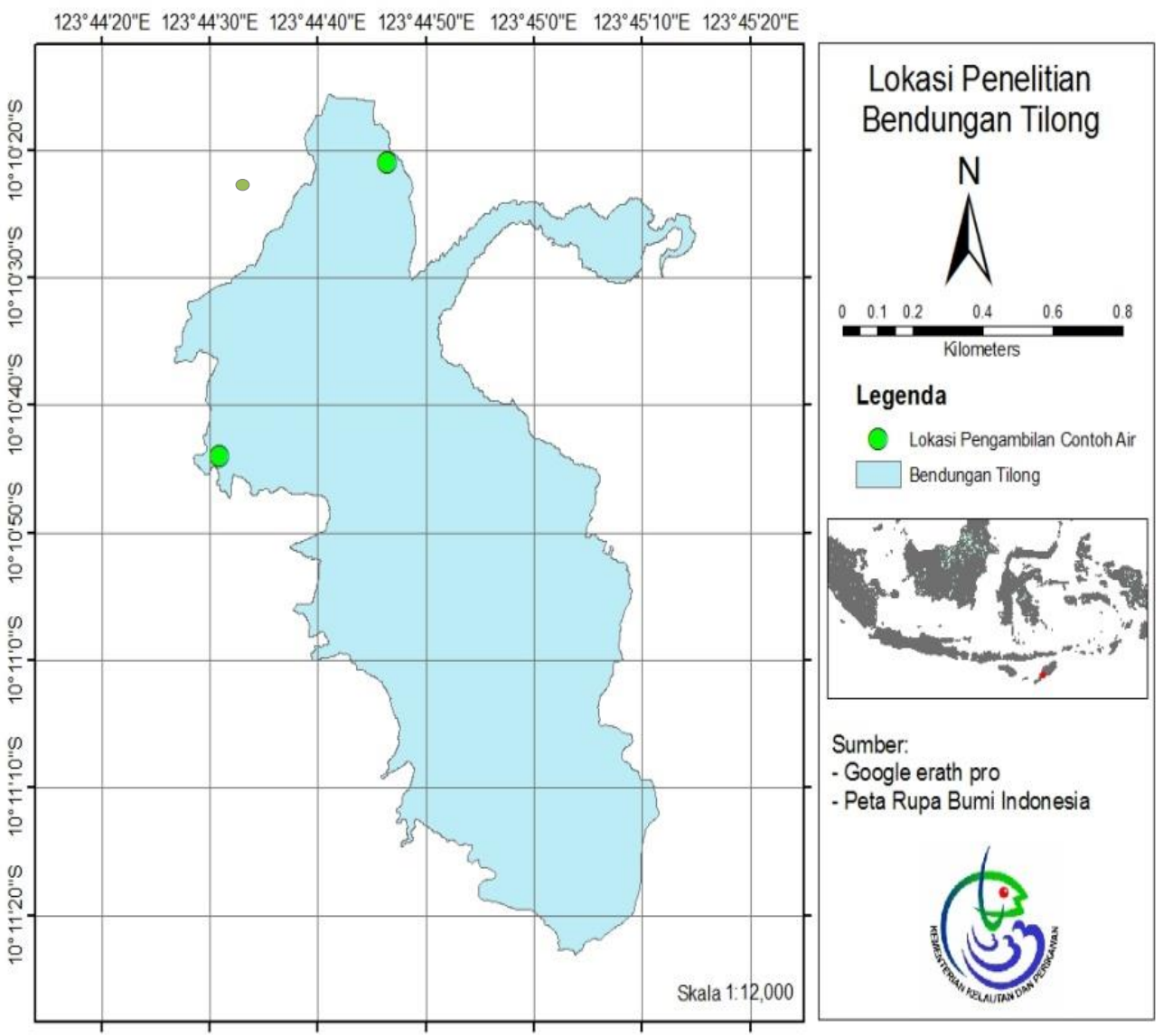

Gambar 2 Lokasi pengambilan contoh air di waduk Tilong 
Tabel 1 Parameter yang diamati serta alat/metode yang digunakan

\begin{tabular}{lll}
\hline Parameter & Satuan & Metode/alat \\
\hline $\begin{array}{l}\text { Suhu air } \\
\text { Kecerahan }\end{array}$ & ${ }^{\circ} \mathrm{C}$ & YSI Professional \\
$\mathrm{pH}$ & $\mathrm{cm}$ & $\begin{array}{l}\text { Keping sechi } \\
\text { YSI Professional }\end{array}$ \\
$\begin{array}{l}\text { Oksigen terlarut } \\
\text { Daya hantar listrik }\end{array}$ & $\mathrm{mg} / \mathrm{L}$ & YSI Professional \\
$\begin{array}{l}\text { Padatan terlarut } \\
\text { total }\end{array}$ & $\mathrm{mg} / \mathrm{L}$ & YSI Professional \\
\hline
\end{tabular}

\section{Pendugaan potensi produksi ikan}

Potensi produksi ikan suatu badan air dapat diprediksi berdasarkan morfometri, nutrien dan iklim (Ryder, 1965). Model morfoedafik indeks mampu memprediksi produksi ikan di perairan waduk kecil di Punjab, Pakistan (Janjua dkk., 2008) dan mempunyai korelasi dengan hasil tangkapan lestari (Sugunan dkk., 2002). Produksi perikanan di beberapa perairan di Sri Lanka di pengaruhi oleh parameter morfoedafik (Nissanka dkk., 2000). Pendekatan yang dapat digunakan untuk mengestimasi potensi produksi berdasarkan indeks morfoedafik (rasio antara daya hantar listrik terhadap kedalaman rata-rata) dengan menggunakan persamaan dari Henderson and Welcomme (1974):

$$
\mathrm{Y}=14,3136 \mathrm{MEI}^{0,4681}
$$

dimana:

$$
\begin{array}{lll}
\mathrm{Y} & : & \text { Potensi produksi }(\mathrm{kg} / \mathrm{ha} / \mathrm{tahun}) \\
\mathrm{MEI} & : & \text { Indeks morfoedafik }(\mu \mathrm{mhos} / \mathrm{cm} / \mathrm{m})
\end{array}
$$

\section{Perhitungan keperluan benih untuk penebaran}

Jumlah benih yang ditebar dapat diestimasi berdasarkan potensi produksi menggunakan parameter daya hantar listrik (Wijeyaratne dan Amarasinghe, 1984). Pendugaan jumlah benih untuk ditebar dalam kegaiatan CBF pada embung di NTT diestimasi dengan menggunakan beberapa pendekatan yaitu:

A. Indeks morfoedafik (Sugunan et al., 2002).

$$
S=\frac{M S Y_{e s t}-Y_{e s t}}{W} * e^{-z\left(t_{1}-t_{0}\right)}
$$

dimana:

$\begin{array}{ll}\mathrm{S} & : \begin{array}{l}\text { Jumlah benih yang ditebar } \\ \text { (ind/tahun/ha) }\end{array} \\ \mathrm{W} & : \begin{array}{l}\text { Berat saat ikan di panen } \\ \text { (kg/ind) }\end{array} \\ \mathrm{Z} & : \text { Laju kematian total (per tahun) } \\ \mathrm{t}_{1} & : \text { Umur saat ditangkap (tahun) } \\ \mathrm{t}_{\mathrm{o}} & : \text { Umur saat di tebar (tahun) }\end{array}$

$$
\begin{array}{llll}
\text { MSYest }: & \text { Hasil tangakapan lestari } \\
& \text { estimasi (kg/ha/tahun) } \\
\text { Yest }: \begin{array}{l}
\text { Hasil tangkapan estimasi } \\
(\mathrm{kg} / \mathrm{ha} / \text { tahun })
\end{array}
\end{array}
$$

Pendekatan hasil tangkapan lestari berdasarkan parameter indeks morfoedafik menggunakan persamaan sebagai berikut:

$$
\mathrm{Y}=0,9897 \mathrm{MEI}^{1,3888}
$$

dimana:

$$
\begin{array}{lll}
\text { Y : } & \begin{array}{l}
\text { Hasil tangkapan lestari } \\
(\mathrm{kg} / \mathrm{ha} / \text { tahun })
\end{array} \\
\text { MEI : } & \begin{array}{l}
\text { Indeks } \\
(\mu \mathrm{mhos} / \mathrm{cm} / \mathrm{m})
\end{array}
\end{array}
$$

Pendekatan lain yang dapat digunakan untuk jumlah benih yang ditebar berdasarkan persamaan Welcomme dan Bartley (1998):

$$
\mathrm{S}=(\mathrm{qp} / \widehat{\mathrm{w}}) \exp \left(-\mathrm{Z}\left(\mathrm{t}_{\mathrm{c}}-\mathrm{t}_{\mathrm{o}}\right)\right.
$$

dimana:

S : Jumlah penebaran (ekor)

q : Potensi produksi ikan (kg/ha/tahun)

$\mathrm{p}$ : Proporsi hasil tangkapan jenis ikan yang ditebar (\%)

$\widehat{\mathrm{w}}$ : Rata-rata berat ikan hasil tangkapan (kg/ekor)

Z : Mortalitas total (per tahun)

$\mathrm{t}_{\mathrm{c}}$ : Umur pada waktu tertangkap (tahun)

$t_{0}$ : Umur pada saat penebaran (tahun)

\section{PEMBAHASAN}

\section{Kondisi biolimnologi}

Penebaran ikan pada suatu badan air harus berlandaskan pada kajian ilmiah mengenai potensi produksi badan air dan kondisi biolimnologi badan air. Kajian ini akan menjadi landasan dalam perhitungan jumlah benih optimal yang dapat ditebar. Ketersediaan pakan alami berupa fitoplankton juga perlu diketahui. Keberhasilan kegiatan CBF pada suatu badan air ditunjang oleh dukungan ketersediaan benih serta peran serta masyarakat dalam pengelolaan badan air (Koeshendrajana dan Purnomo, 2009). Oleh karena itu perlu adanya data tersebut sebagai bahan pertimbangan dalam pemilihan lokasi untuk pengembangan $\mathrm{CBF}$.

Suhu air dan konsentrasi oksigen terlarut merupakan parameter yang mempengaruhi konsumsi pakan dan laju metabolism pada ikan (Natarajan dkk., 2009; Sapkale dkk., 2011). Kondisi limnologi waduk Tilong hampir sama dengan kondisi limnologi beberapa lokasi badan air untuk kegiatan CBF (Jayasinghe dkk., 2005). Ikan 
bandeng dan nila dapat tumbuh dengan baik pada perairan dengan suhu masing-masing berkisar 24$33^{\circ} \mathrm{C}$ (Villaluz dan Unggui, 1983 ) dan $26-30^{\circ} \mathrm{C}$ (Azaza dkk., 2008; Dos Santos dkk., 2013). Laju pertumbuhan ikan juga dipengaruhi oleh $\mathrm{pH}$ air, misalnya ikan mas akan tumbuh optimal pada $\mathrm{pH}$ 7-8 (Tiwary dkk., 2013) sedangkan ikan koan pada pH 8 (Vasudhevan dkk., 2014). pH perairan akan mempengaruhi aktivitas enzim pencernaan pada ikan (Jian-Sheng dkk., 2013).

Parameter kualitas air dapat menggambarkan kondisi lingkungan dan kelayakannya bagi kehidupan ikan. Suhu air di waduk Tilong berkisar 29,9-34,5 oC dengan nilai pH berkisar 7,65-8,21. Konsentrasi oksigen terlarut berkisar 4,03-4,85 $\mathrm{mg} / \mathrm{L}$ dengan nilai kekeruhan berkisar 12,5-16,1 NTU serta daya hantar listrik berkisar 441,5-452,2 $\mu \mathrm{s} / \mathrm{cm}$. Nilai kekeruhan cukup tinggi sehingga menyebabkan rendahnya nilai kecerahan yaitu berkisar 100-210 cm. Potensi produksi waduk Tilong yang dihitung berdasarkan indeks morfoedafik sebesar 75,96-77,48 kg/ha/tahun atau sebesar 11,87-12 ton/tahun. Nilai pH dan oksigen terlarut di waduk Tilong hampir sama dengan waduk Jatiluhur yang merupakan lokasi penebaran ikan nila dan bandeng masing-masing berkisar 7,0-9,0 dan 3,5-5,6 mg/L (Tjahjo dan Suman, 2009; Tjahjo dan Purnamaningtyas, 2008b). Nilai suhu air, pH, oksigen terlarut dan daya hantar listrik di waduk Tilong juga sama dengan di badan air yang merupakan lokasi penebaran ikan Sri Lanka yaitu 27,8-32oC; 6,7-9,0; 2,58-6,77 mg/L dan 350-430 $\mu \mathrm{s} / \mathrm{cm}$ (Jayasinghe dkk., 2005).

Ketersediaan pakan alami merupakan salah satu syarat keberhasilan penebaran ikan. Kelimpahan fitoplankton di Waduk Tilong berkisar 1197-38332 sel/liter. Kelas fitoplankton yang ditemukan di waduk Tilong adalah Bacillariophycea, Chlorophyceae, Cyanophyceae, dan Dinophyceaea yang terdiri dari 11 genera. Genera dengan kelimpahan yang tinggi Anabaena sp, Mycrocystis sp dan Oscillatoria sp, dan Peridinium sp. Biomassa fitoplankton yang dihitung berdasarkan biovolume sebesar 0,151 $\mathrm{mg} / \mathrm{m} 3$. Ikan nila mampu memanfaatkan keempat genera fitoplankton tersebut (Assefa dan Getahun, 2015; Semyalo dkk., 2011). Ikan bandeng juga mampu memanfaatkan Mycrocystis sp., Peridinium sp., dan Anabaena sp sebagai pakan alami sebesar (10-31.1\%) dan Oscilatoria sp (1,727\%) (Triyanto dkk., 2014).

Penebaran ikan nila dan bandeng mampu mengatasi blooming cyanophyceae di waduk Jatiluhur (Tjahjo dan Purnamaningtyas 2009). Penebaran ikan bandeng berdampak positif terhadap komunitas ikan di waduk Jatiluhur
(Hedianto dan Purnamaningtyas 2011). Keberadaan ikan nila dapat mengurangi kelimpahan Chlorophyceae (Scenedesmus, Ankistrodesmus dan Tetraedron) dan Cyanobacteria (Microcystis). Ikan nila dapat beradaptasi pada kondisi kualitas air yang buruk dan oksigen rendah (Njiru dkk. 2004) serta menekan populasi fitoplankton yang berukuran kecil (Turker dkk. 2003) dimana ikan nila memanfaatkan fitoplankton $(81,2 \%)$ sebagai pakan utamanya (Tjahjo dan Purnomo 1998). Ikan nila di danau Tempe memanfaatakan fitoplankton $(85,95 \%)$ sebagai pakan utamanya sedangkan pemanfaatan tumbuhan hanya sebesar 11,83\% (Samuel dan Makmur 2011). Penebaran ikan nila di waduk Jatiluhur berdampak pada peningkatan hasil tangkapan sebesar 6,4\% (Kartamihardja dan Hardjamulia 1983). Kelimpahan fitoplankton yang tinggi di waduk Jatiluhur dapat dimanfaatan oleh ikan bandeng yang ditebar sehingga mempunyai laju pertumbuhan yang cepat (Tjahjo dkk., 2011).

\section{Potensi pengembangan CBF}

Potensi perikanan di waduk Tilong belum dikembangkan secara optimal. Hal ini diindikasikan dengan belum adanya masyarakat yang berprofesi sebagai nelayan baik sebagai mata pencaharian tetap maupun sampingan. Upaya yang telah dilakukan oleh pemerintah daerah untuk mengoptimalkan fungsi waduk dalam bidang perikanan adalah penebaran ikan nila (Oreochromis niloticus). Namun kegiatan penebaran tersebut dampaknya belum dirasakan oleh masyarakat. Jika alokasi hasil tangkapan lestari adalah $60 \%$ dari potensi produksi (Kartamihardja dkk., 2010) maka produksi ikan yang dapat dieksploitasi sebesar 7,1-7,2 ton/tahun.

Introduksi dan penebaran serta kegiatan budidaya merupakan teknik yang digunakan untuk peningkatan produksi ikan dari perairan umum daratan di Asia (De Silva, 2016). Produksi perikanan perairan umum mencapai 187,7 $\mathrm{kg} / \mathrm{ha} /$ tahun dan sekitar $40 \%$ berasal dari perairan danau atau waduk (Li, 1999). Perikanan tersebut bertumpu pada penebaran dan penangkapan kembali (De Silva dkk., 1991). Penebaran ikan nila dapat meningkatan hasil tangkapan pada beberapa waduk di Brazil (Attayde dkk., 2011).

Pemenuhan kebutuhan benih ikan untuk penebaran didukung oleh Balai Benih Ikan (BBI) yang ada di 15 Kabupaten di Propinsi Nusa Tenggara Timur. Benih ikan yang di hasilkan di BBI tersebut antara lain nila, mas, bandeng, lele, gurame tawes dan udang. Produksi benih beberapa jenis ikan disajikan pada Gambar 3. 


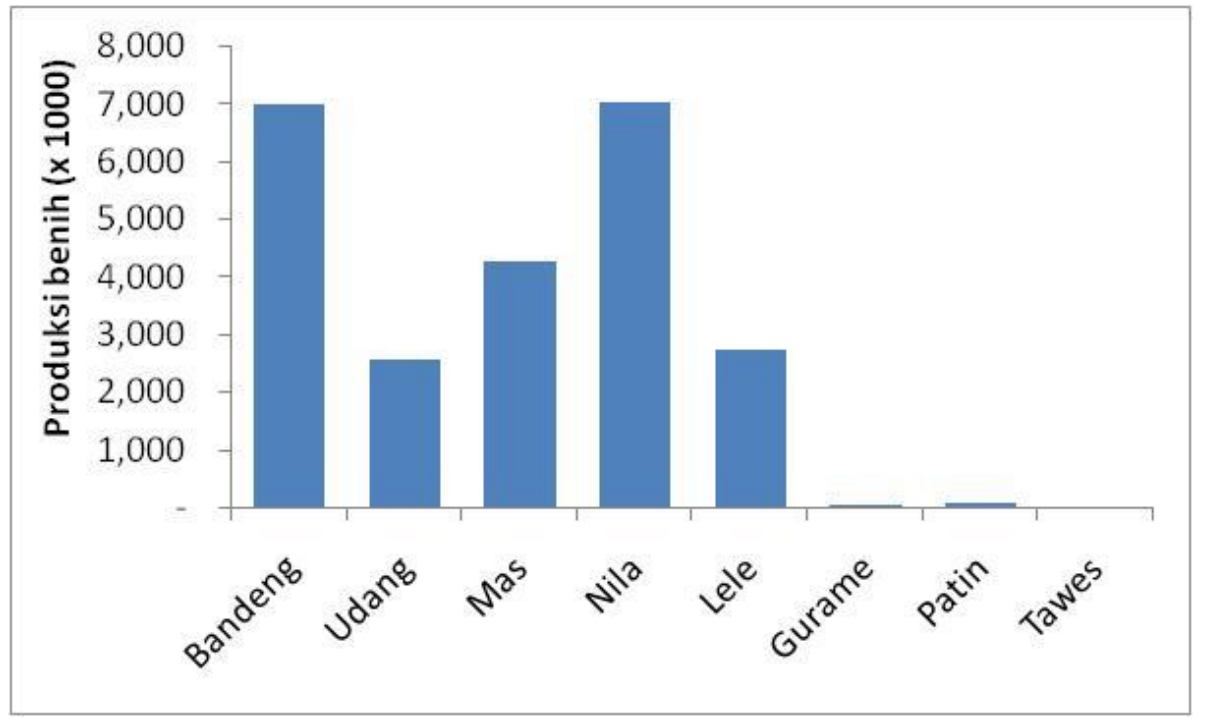

Gambar 3 Produksi benih ikan di NTT tahun 2015

Benih ikan nila, mas dan bandeng merupakan benih benih ikan dengan produksi tertinggi. Produksi benih ikan nila, mas dan bandeng pada tahun 2015 masing-masing berjumlah 7.040.770; 4.280.920 dan 7.023.400 ekor. Benih ikan bandeng dan nila telah di hasilkan di BBI pada 13 Kabupaten di NTT. Produksi benih ikan bandeng terbanyak terdapat di BBI Kabupaten Kupang sedangkan benih ikan nila tertinggi dihasilkan di BBI Kabupaten Timur Tengah Selatan. Kedua jenis ikan tersebut merupakan jenis ikan yang menjadi kandidat untuk ditebar. Selain produksi benih ikan, waktu dan ukuran benih ikan juga harus diperhatikan. Penebaran benih ikan diperlukan ukuran 8-10 cm untuk menurunkan angka mortalitas alami ikan (Warsa dkk., 2018).

Jenis ikan yang umumnya ditebar di perairan antara lain nila, patin dan bandeng (Umar dan Sulaiman 2013). Ikan yang menjadi pilihan untuk ditebar adalah ikan nila dan bandeng hal ini didasarkan pada ketersediaan benih dan telah berhasil di tebar pada beberapa badan air. Selain itu ikan bandeng mempunyai laju pertumbuhan yang cepat (Tjahjo dkk., 2011) sedangkan ikan nila mampu bertahan pada kondisi kualitas air yang buruk.

Benih bandeng dan nila yang ditebar di waduk Jatiluhur masing-masing mempunyai berat 5,1 g (Tjahjo dkk., 2011) dan 20 g (Krismono, 1989) dengan ukuran ikan tebaran yang boleh ditangkap adalah 250 g. Parameter biologi ikan nila dan bandeng yang menjadi dasar perhitungan jumlah benih disajikan pada tabel 2 .

Jumlah benih bandeng yang dibutuhkan untuk penebaran di waduk Tilong berkisar 33.100-36800 ekor/tahun (213-237 ekor/ha) sedangkan untuk ikan nila berkisar 33.900-37700 ekor/tahun (218243 ekor/ha). Kepadatan benih untuk CFB di waduk Tilong ini tidak-berbeda jauh dengan waduk Kuilekada, Sri Lanka yaitu 217 ekor/ha (Pushpalatha dan Chandrasoma, 2010). Estimasi hasil berdasarkan kepadatan benih tebar (Sugunan dan Katiha, 2004; Kartamihardja, 2015) maka produksi ikan tebaran adalah 14,3 kg/ha atau 2,2 ton. Ikan bandeng dan nila dengan ukuran $250 \mathrm{~g}$ mempunyai umur estimasi masing-masing adalah 5 dan 6 bulan. Untuk mencapai ukuran layak tangkap, ikan tebaran membutuhkan waktu 4 bulan. $\quad \mathrm{CBF}$ dapat menyumbang produksi perikanan perikanan tangkap sebesar $10 \%$ dari suatu badan air (Lorenzen, 2001).

Tabel 2 Parameter populasi dan biologi kandidat ikan tebaran

\begin{tabular}{lrr}
\hline $\begin{array}{l}\text { Parameter } \\
\text { populasi/biologi }\end{array}$ & Nila* $^{*}$ & Bandeng** $^{* *}$ \\
\hline Loo $(\mathrm{cm})_{\mathrm{K}\left(\text { tahun }^{-1}\right)}$ & 44,1 & 88,42 \\
$\mathrm{M}\left(\right.$ tahun $\left.^{-1}\right)$ & 0,72 & 0,95 \\
$\mathrm{~A}$ & 1,34 & 3,5891 \\
$\mathrm{~B}$ & 0,129 & 0,0113 \\
$\mathrm{~W}_{\mathrm{o}}(\mathrm{g})$ & 2,4608 & 2,9744 \\
$\mathrm{~W}_{\mathrm{h}}(\mathrm{g})$ & 20 & 5 \\
Sumber:Putri and Tjahjo (2010) dan Tjahjo dkk.(2011)
\end{tabular}

Jika mengacu pada biomassa ikan bandeng total yang dipanen maka biomassa tertinggi yang dihasilkan jika ikan ditangkap pada ukuran 100 g/ekor. Namun jika dikoreksi dengan harga untuk setiap kilogram ikan, maka nilai ekonomi tertinggi terjadi jika ukuran tangkap adalah 200 g/ekor atau pada umur 0,4 tahun (5,8 bulan). Produksi ikan nila 
tertinggi jika ikan ditangkap pada ukuran 100/ekor namun nilai ekonomi tertinggi terjadi jika ikan ditangkap pada ukuran $150 \mathrm{~g}$ /ekor atau pada umur 0,35 tahun (4,2 bulan) (Gambar 4). Untuk mencapai bobot tersebut maka dibutuhkan waktu selama 4,0 untuk ikan bandeng dan 3,5 bulan untuk ikan nila setelah penebaran. Jika harga jual dari ikan bandeng dan nila masing-masing adalah Rp 18000 dan Rp 25000 maka dalam satu kali penebaran dapat menghasilkan Rp 20.500.000 untuk ikan nila dan Rp 21.500.000. untuk ikan bandeng.

Dukungan masyarakat sekitar menjadi salah satu faktor yang berpengaruh terhadap keberhasilan program CBF. Di sekitar waduk Tilong belum ada kelembagaan masyarakat khusus perikanan. Namun telah terdapat kelembagaan pertanian yang juga berperan dalam pengelolaan badan air. Organisasi tersebut telah mempunyai struktur serta agenda pertemuan yang teratur. Selain itu juga telah ada Peraturan Desa dalam pemanfaatan waduk Tilong. Peraturan tersebut telah diikuti oleh msayarakat desa. Hal ini diperlukan karena penebaran ikan bandeng harus dilakukan secara berkala disebabkan oleh ikan bandeng tidak dapat berkembang biak. Selain itu untuk memupuk kemandirian dalam penebaran diperlukan penggalangan dana dari hasil tangkapan ikan tebaran untuk pembelian benih selanjutnya. Koordinasi dengan BBI juga diperlukan agar ketersediaan benih dengan ukuran yang tepat dapat terpenuhi sesuai dengan jadwal penebaran yang telah disepakati.

Upaya peningkatan produksi perikanan dengan penebaran ikan menggunakan pola perikanan tangkap berbasis budidaya sudah umum dilakukan di Indonesia (Kartamihardja, 2015).
Penebaran ikan ikan di Waduk Malahayu dengan padat tebar dapat memberikan hasil tangkapan sebesar 545 ton/tahun (Warsa \& Purnomo, 2011). Kegiatan penebaran ikan di perarian umum daratan di Vietnam dan Sri Lanka memberikan dampak peningkatan produksi perikanan berkisar 23-51\% dan 43\% (Pushpalatha \& Chandrasoma, 2010; Nguyen dkk, 2005). Dengan demikian, peningkatan produksi ikan dengan penebaran ikan di Waduk Tilong akan mempunyai tingkat keberhasilan yang tinggi.

\section{KESIMPULAN}

Kondisi limnologi yang mendukung kehidupan ikan, ketersediaan benih serta dukungan kelembagaan masyarakat. Jenis ikan yang menjadi kandidat tebaran adalah ikan bandeng dan nila dengan jumlah benih masing-masing adalah 71.000-73.500 ekor/tahun dan 72.000-75.000 ekor/tahun. Penebaran ikan dapat menghasilkan produksi tangkapan ikan sebesar $40 \%$ dari potensi perikanan dengan nilai ekonomi sebesar $\mathrm{Rp}$ 20.500 .000 dan Rp 21.500.000. Berdasarkan faktor-faktor tersebut maka waduk Tilong layak untuk pengembangan perikanan tangkap dengan teknik Perikanan Tangkap Berbasis Budidaya.

\section{UCAPAN TERIMA KASIH}

Penulis mengucapkan terima kasih kepada Dinas Kelautan dan Perikanan Propinsi NTT dan Balai Besar Wilayah Sungai Nusa Tenggara II (BWSNT II) atas izin yang diberikan dalam penggunaan data dan informasi. Prof Krismono atas saran yang diberikan serta Dedi Sumarno, A. Md dan Hendra Saepulloh atas bantuannya selama penelitian.

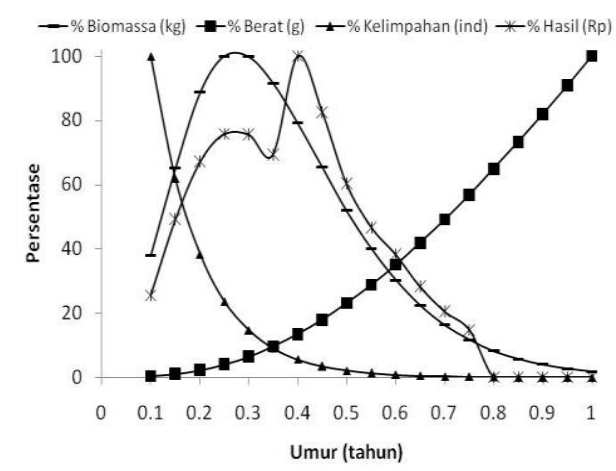

A

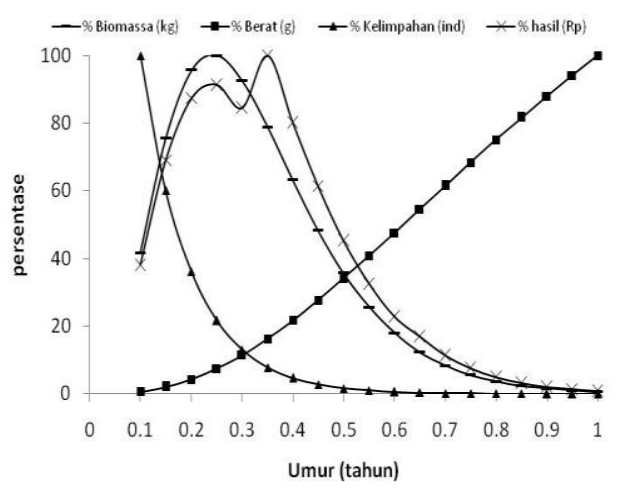

B

Gambar 4 Grafik umur terhadap kelimpahan relatif, biomassa relatif dan nilai ekonomi A ikan bandeng B. ikan nila 


\section{DAFTAR PUSTAKA}

Ahab, S. J.C., M.L. Lily, \& T.B. Prayoga. (2016) Kajian Perubahan Iklim terhadap limpasan permukaan di DAS Noelbaki. Jurnal Teknik Pengairan, 7(1),117-128. Mei. 2016.

An, K.G., \& J.R. Jones. (2000). Factor regulating bluegreen dominance in a reservoir directly influenced by the Asian monsoon. Hydrobiologia, 432, 37-48. DOI: 10.1023/A:1004077220519.

Assefa, W.W., \& A. Getahun. (2015). The food and feeding ecology of nile tilapia, Oreochromis niloticus, in Lake Hayq, Ethiophia, International Journal of Fisheries and Aquatic Studies 2(3),176185. DOI: $10.1023 / \mathrm{A}: 1004077220519$

Attayde J.L., J. Brasil, \& R.A. Menescal. (2011). Impact of introducing nile tilapia on fisheries of a tropical reservoir in North-Eastern. Fisheries Management and Ecology, 18,437-443. DOI: 10.1111/j.1365-2400.2011.00796.x

Averhoff, O.R.L. (1999). Fish yield in Cuban reservoirs and relationships with some morphometric and edaphic parameters. Lakes \& Reservoirs: Research and Management, 4, 75-83. DOI: 10.1046/i.1440-1770.1999.00082.x

Azaza M.S., M.N. Dhraief, \& M.M Kraiem. (2008). Effect of water temperature on growth and sex ratio of juvenile nile tilapia Oreochromis niloticus (Linnaeus) reared in geothermal water in southern Tunisi. Journal of Thermal Biology, 33,98-105.

doi.org/10.1016/j.jtherbio.2007.05.007

De Silva S.S., Y. Zhitang, \& X. Lin-HU. (1991). A brief review of the status and practices of the reservoir fishery in mainland China. Aquaculture and Fisheries Management, 22,73-84. DOI: 10.1080/1045988X.2014.919136

De Silva, S.S. (2003). Culture-based fisheries: an underutilized opportunity in aquaculture development. Aquaculture. 221, 221-243. DOI: 10.1016/S0044-8486(02)00657-9

De Silva, S.S., \& S.J. Funge-Smith. (2005). A review of stock enhancement practices in the inland water fisheries of Asia. Asia-Pacific Fishery Commission, Bangkok, Thailand. RAP Publication No. 2005/12.
De Silva, S.S., \& S.L. Song. (2015). Challenges and constraints for developing CBF in Cambodia and a possible strategy for success. In Sena S. De Silva, B.A. Ingram and S. Wilkinson (eds.), Perspectives on culture-based fi sheries developments in Asia, Bangkok, Thailand: Network of Aquaculture Centres in Asia-Pacific.

De Silva, S.S. (2016). Cultured based fisheries in Asia are strategy to augment food security. Food Security, 8(3), 585-596. DOI: 10.1007/s12571$\underline{016-0568-8}$

Dillon, P.J., \& F. H. Rigler. (1975). A simple method for predicting the capacity of a lake for development based on lake trophic status. Journal of the Fisheries Research Board of Canada, 32, 15191531. doi.org/10.1139/f75-178

Dos Santos, V.B., E.A. Mareco, \& M.D.P. Silva. (2013). Growth curve of nile tilapia (Oreochromis niloticus) strain cultived at different temperature. Maringa, 35(3), 235-242. DOI: 10.4025/actascianimsci.v35i3.19443

Fallo, Y., Rispiningtati, \& D. Harisuseno. (2013). Analisa perubahan tataguna lahan terhadap usia bendungan Tilong di DAS Tilong Kabupaten Kupang Propinsi NTT. Jurnal Pengairan, 4(2), 113.

FAO. 1997. Aquaculture development. FAO Technical Guidelines for Responsible Fisheries 5. Rome: FAO.

Gomes, L.C., L.E. Miranda, \& A.A. Agostinho. (2002). Fishery yield relative to chlorophyll a in reservoirs of Upper Parana River, Brazil. Fisheries Research, 55, 335-340. DOI: 10.1016/S01657836(01)00278-8

Hedianto D. A., \& S. E. Purnamaningtyas. (2011). Penerapan kurva ABC (Rasio kelimpahan/biomassa) untuk mengevaluasi dampak introduksi terhadap komunitas ikan di Waduk Ir. H. Djuanda. Dalam Kartamihardja ES. Rahardjo MF, Purnomo K (Eds). Prosiding Nasional Pemacuan Sumberdaya Ikan III (hal.111). Purwakarta: Balai Penelitian Pemulihan dan Konservasi Sumberdaya.

Henderson, H.F., \& R.L. Welcomme. (1974). The relationship of yield to morphoedaphic index and number of fisherman in Africa inland waters. Comminte for Inland Fisheries in Africa, Occas Pap 1. Rome: FAO 
Janjua, M.Y., T. Ahmad, \& D. Gerdeaux. (2008). Comparison of different models for estimating fish yield in Shahpur Dam, Pakistan. Lake \& Reservoirs: Research and Management, 13, 319324. DOI: $10.1111 /$ i.1440-1770.2008.00377.x

Jayasinghe, U.A.D., U.S Amarasinghe, \& S.S. De Silva. (2005). Limnology and culture-based fisheries in non-perennial reservoirs in Sri Lanka. Lake \& Reservoirs: Research and Management, 10(3), 157-166.

doi.org/10.1111/j.14401770.2005.00271.x

Jayasinghe, U.A.D., U.S. Amarasinghe, \& S.S. De Silva, S. S. (2006). Culture-based fisheries in nonperennial reservoirs of Sri Lanka: influence of reservoir morphometry and stocking density on yield. Fisheries Management and Ecology, 13, 157-164.

DOI: $\underline{10.1111 / j .1365-}$ 2400.2006.00488.x

Jian-Sheng, Y., C. Xiao-Jiang, \& Z. Yong-yong. (2013). Influence of $\mathrm{pH}$ on survival, growth and activities of digestive enzymes of Odontobutis obscures. Advance Journal of Food Science and Tecnology, 5(9), 1234-1237. DOI: 10.19026/ajfst.5.3088

Kartamihardja, E. S., \& A. Hardjamulia. (1983). Kontribusi penebaran ikan nila (Oreochromis niloticus) terhadap produksi ikan Waduk Jatiluhur, Jawa Barat. Bulletin Perikanan Darat, 4(1), 37-40.

Kartamihardja, E.S., \& K. Purnomo. (2005). Keberhasilan introduksi ikan patin siam (Pangasius hypophthalmus) dan dampaknya terhadap komposisi dan hasil tangkapan ikan di Waduk Wonogiri, Jawa Tengah. Dalam Wiadnyana, N.N., Kartamihardja, E.S., Hartoto, D.I., Sarnita, A dan Sunarno, M.T.D (eds.) Prosiding Forum Perairan Umum Indonesia I. Palembang (hal.321-325).

Kartamihardja E. S., K. Purnomo, \& C. Umar. (2009). Sumberdaya ikan perairan umum daratan di Indonesia-Terabaikan. Jurnal Kebijakkan Perikanan Indonesia, 1(1), 1-15. DOI: 10.15578/jkpi.1.1.2009.1-15.

Kartamihardja, E, S., K. Purnomo., D.W.H. Tjahjo. C Umar., M.T.D. Sunarno, \& S. Koeshedrajana. (2010). Petunjuk Teknis: Pemulihan sumberdaya ikan di perairan umum daratan Indonesia. Jakarta: Pusat Penelitian Pengelolaan Perikanan dan Konservasi Sumberdaya Ikan.
Kartamihardja, E.S. (2012). Stock enhancement in Indonesian lake and reservoirs fisheries. Indonesian Fisheries Research Journal, 18(2), 91100.

DOI: http://dx.doi.org/10.15578/ifrj.18.2.2012.91100

Kartamihardja, E.S. (2015). Potential of culture-based fisheries in Indonesian inland waters. In de Silva SS, Ingram BA and Wilkinson S (eds). Perspectives on cultuttre-based-fisheries developments in Asia (73-81). Bangkok. Thailand. Network of Aquaculture Centres in Asia-Pacific.

Koeshendrajana, S., \& K. Purnomo. (2009). Kriteria bioekologi, sosial ekonomi dan kelembagaan dalam penentuan lokasi bagi pengembangan perikanan tangkap berbasis budidaya (Culturebased fisheries/CBF). Dalam Hardianto, D dan Muh, Taufiqurrohman (Eds), Prosiding seminar nasional kelautan $V$. Universitas Hang Tuah: Surabaya (hal.32-40).

Krismono. (1989). Komunitas ikan di Waduk Jatiluhur selama 5 tahun (1982-1986). Bulletin Penelitian Perikanan Darat, 8(2),40-49.

Li, J. (1999). An appraisal of factors constraining the success of fish stock enhancement programmes. Fisheries Management and Ecology, 6. 161-169. https://doi.org/10.1046/j.13652400.1999.00145.x

Lorenzen, K., U.S. Amarasinghe., D.M. Bartley., J.D. Bell., M. Bilio., S.S. de Silva., C.J. Garaway., W.D. Hartmann., J.M. Kapetsky., P. Laleye., J. Moreau., V.V. Sugunan, \& D.B. Swar. (2001). Strategic Review of enhancements and culture-based fisheries. In Subasinghe RP, Bueno P, Phillips MJ, Hough C, McGladdery SE (Eds). In Aquaculture in the Third Millennium. Technical Proceedings of the Conference on Aquaculture in the Third Millennium, Bangkok, Thailand (pp.221-237).

Ludiana., W. Bunganaen, \& T.M.W. Sir. (2015). Evaluasi kinerja jaringan irigasi bendungan tilong kecmatan Kupang Tengah Kabupaten Kupang. Jurnal Teknik Sipil, IV (1), 17-28.

Moreau, J., \& S. S De Silva. (1991). Predictive fish yield models for lakes and reservoirs of the Phillipines, Sri Lanka and Thailand. FAO Fish. Tech. Rome: FAO.

Mustapha, M. K. (2009). Limnological evaluation of the fisheries potentials and productivity of a small shallow tropical African reservoir. Revista Biologia Tropical, 57(4), 1093-1106. ISSN-00347744) 
Natarajan, M., P, Raja., G, Maricahmy., \& R, Rajagopal. (2009). Effect of temperature, dissolved oxygen variation and evaporation rate in marine aquarium. Current Research Journal of Biological Science, 1(3), 72-77. ISSN: 2041-0778

Nguyen, S. H., A.T. Bui., L.T. Le., T.T.T. Nguyen, \& S.S. De Silva. (2001). The culture-based fisheries in small, farmer-managed reservoirs in two Provinces of northern Vietnam: an evaluation based on three production cycles. Aquaculture Research, 32, 975-990. DOI: 10.1046/i.13652109.2001.00633.x

Nguyen, H.S., A.T. Bui., D.Q. Nguyen., D.Q. Truong., L.T. Le., N.W. Abery, \& S.S. De Silva (2005). Cultured-based fisheries in small reservoirs in north Vietnam: effect stocking density and species combination. Aquaculture Research, 36,1037-1048.

doi:10.1111/j.13652109.2005.01312.x

Nissanka, C., U.S. Amarasinghe, \& S.S. De Silva. (2000). Yiled predictive models for Sri Lanka reservoirs Fisheries. Fisheries Management and Ecology, 7, 425-436. DOI: 10.1046/i.1365$\underline{2400.2000 .00212 . x}$

Njiru, M., J.B. Okeyo-Owur., M. Muchiri, \& I.G. Cowx. (2004). Shift in feeding ecology of nile tilapia in Lake Victoria, Kenya. African Journal of Ecology, 42, 163-170. DOI: $10.1111 / \mathrm{j} .1365-$ 2028.2004.00503.x

Palys, T. (2008). Purposive sampling. In Given, L. M (Edt). The Sage Encyclopediaof Qualitative Research Methods 2. Los Angeles: Sage

Phan, P.D., \& S.S. De Silva. (2000). The fishery of the Ea Kao reservoir, southern Vietnam: a fishery based on a combination of stock and recapture, and self-recruiting populations. Fisheries Management and Ecology 7, 251-264. doi.org/10.1046/i.1365-2400.2000.00192.x

Prianto, E., C. Umar., E.S. Kartamihardja, \& Husnah. (2017). Pengelolaan dan pemanfaatan perairan embung dan bendungan di Provinsi Nusa Tenggara Timur. Jurnal Kebijakan Perikanan Indonesia, 9(2), 105-114. DOI: 10.15578/jkpi.9.2.2017.105-114

Purnomo, K. (2011). Pertumbuhan, mortalitas dan preferensi makanan ikan nila (Oreochromis niloticus) di Waduk Malahayau. Dalam Isnansetyo A. Djumanto, Suadi (Eds). Yogyakarta: Prosiding Seminar Nasional Tahunan VIII. (hal.19)
Pushpalatha, K. B. C., \& J. Chandrasoma. (2010). Cultur-based fisheries in minor perennial reservoirs in Sri Lanka: Variability in production, stoked species and yield implications. J. Appl. Ichthyol 26, 99-104. DOI: 10.1111/i.14390426.2009.01361.x

Quiros, R. (1999). The relationship between fish yield and stocking density in reservoirs from tropical and temperate regions. Theoritical Reservoir Ecology and its Applications: In Tundisia, J.G and M. Straskraba. Brazil. Internationale Institute of Ecology, Brazilian Academy of Sciences and Bckhuys Publisher. (pp. 67-83).

Ryder, R.A. (1965). A methods for estimating the potential fish production of North-temperate Lakes. Transaction of the American Fishery Society 94, 214-218. doi.org/10.1577/15488659(1965)94[214:AMFETP]2.0.CO;2

Samuel, \& S. Mamur. (2011). Karakteristik biologi beberapa jenis ikan introduksi di Danau Tempe, Sulawesi Selatan. Dalam Kartamihardja ES, Rahardjo MF, Purnomo K (eds). Dalam Prosiding Forum Pemacuan Sumberdaya Ikan III (hal. 1-14). Jakarta: Pusat Riset Perikanan Tangkap.

Sapkale, P.H., R.K. Singh, \& A.S. Desai. (2011). Optimal water temperature and $\mathrm{pH}$ for development of eggs and growth of spawn of common carp (Cyprinus carpio). Journal of Applied Animal Research 39(4), 339-345. doi: 10.1080/09712119.2011.620269

Semyalo, R., T. Rohrlack., D. Kayiira., Y. S. Kizito., S. Byarujali., G. Nyakairu, \& P. Larsson. (2011). On the diet of nile tilpia in two eutrophic tropical lakes containing toxin producing cyanobacteria. Limnologica $41.30-36$. DOI: $10.1016 /$ j.limno.2010.04.002

Sugunan, V.V., S.K. Mandal, \& D.S. Krishna Rao. (2002). Fish yield prediction through morphoedaphic index and estimation of stocking density for stocking density for Indian reservoirs. Indian J. Fish, 49(4), 369-378.

Sugunan, V.V., \& P.K. Katiha. (2004). Impact of stocking on yield in small reservoirs in Andhra Pradesh, India. Fisheries Management and Ecology 11, 65-69. DOI: 10.1046/j.1365$\underline{2400.2003 .00370 . x}$

Tampani, Y. P. S., W. Soetopo, \& D. Harisuseno. (2016). Evaluasi dan simulasi pola operasi Waduk Tilong di Kabupaten Kupang. Jurnal Teknik Pengairan, 7(1), 160-170. 
Tiwary C. B., V.S. Pandey., F. Ali, \& S. Kumar. (2013). Effect of $\mathrm{pH}$ on growth performance and survival rate of grascarp. Scholars Academic Journal of Bioscience, 1(7), 374-376. ISSN 2321-6883

Tjahjo, D.W.H., \& K. Purnomo. (1998). Studi interaksi pemanfaatan pakan alami antara ikan sepat (Trichogaster pectoralis), betok (Anabas testudineus), mujair (Oreochromis mossambicus), nila (O. niloticus) dan gabus (Channa striatus) di Rawa Taliwang. Jurnal Penelitian Perikanan Indonesia, 4 (3), 50 - 59. http://dx.doi.org/10.15578/jppi.4.3.1998.50-59

Tjahjo, D.W.H., \& S.E. Purnamaningtyas. (2008a). Evaluasi keberhasilan penebaran ikan di Waduk Ir. H. Djuanda, Jawa Barat. Dalam Rahardjo M.F., N.N. Wiadnyana., Kartamihardja, E.S., K. Purnomo., Krismono., D.D. Sjafei. dan A.R. Syam (eds). In Forum Nasional Pemacuan Sumberdaya Ikan I (hal. 205-213). Jakarta: Pusat Riset Perikanan Tangkap.

Tjahjo D.W.H., \& S.E. Purnamaningtyas. (2008b). Kajian kualitas air dalam evaluasi pengembangan perikanan di Waduk Ir. H. Djuanda, Jawa Barat. Jurnal Penelitian Perikanan Indonesia, 14(1), 1529. DOI: $10.15578 /$ ippi.14.1.2008.15-30

Tjahjo, D.W.H., \& S.E. Purnamaningtyas. (2009). Evaluasi Evaluasi kemampuan ikan nila dan bandeng tebaran dalam memanfaatkan kelimpahan fitoplankton di Waduk Ir. H. Djuanda. Kartamihardja E.S. M.T.D. Sunarno., N.N. Wiadnyana. M.F. Rahardjo dan Krismono (Eds). Forum Nasional Pemacuan Sumberdaya Ikan II (hal.205-213). Jakarta: Pusat Riset Perikanan Tangkap.

Tjahjo, D.W.H., \& A. Suman. (2009). Pengelolaan perikanan waduk Saguling, Cirata dan Ir. H. Djuanda, Jawa Barat. Jurnal Kebijakan Perikanan Indonesia, 1(2), 113-120. DOI: $10.15578 /$ ikpi.1.2.2009.113-120

Tjahjo, D.W.H., S.E. Purnamaningtyas, \& E.S. Kartamihardja. (2011). Evaluasi keberhasilan penebaran ikan bandeng (Channos channos) di Waduk Ir. H. Djuanda. Bawal, 3(4), 231-237. DOI: http://dx.doi.org/10.15578/bawal.3.4.2011 .231-237

Triyanto., M.M. Kamal, \& N.T.M. Pratiwi. (2014). Pemanfaatan makanan dan pertumbuhan ikan bandeng (Chanos chanos) yang diintroduksi di Waduk Ir. H. Djuanda, Jawa Barat. Limnotek, 21(1), 64-73.
Turker, H., A.G. Eversole, \& D.E. Brune. (2003). Comparative nile tilapia and silver carp filtration rates of partitioned aquaculture system phytoplankton. Aquaculture. 220, 449-457. DOI: 10.1016/S0044-8486(02)00614-2

Umar, C., \& E.S. Kartamihardja. (2011). Hubungan panjang-berat, kebiasaan makan dan kematangan gonad ikan bilih (Mystcaecoleucus padangensis) di Danau Toba, Sumatera Utara. Bawal, 3(6). 351-356. DOI: http://dx.doi.org/10.15578/bawal.3.6.2011 .351-356

Umar, C., \& P. Sulaiman. (2013). Status introduksi ikan dan strategi pelaksanaan secara berkelanjutan di Perairan Umum daratan di Indonesia. Jurnal Kebijakan Perikanan Indonesia, 5(2), 107-112. DOI:

http://dx.doi.org/10.15578/jkpi.5.2.2012.113$\underline{120}$

Vasudhevan, I., K, Asoka., S. Priya., L. Rakitha, \& R. Santhi. (2014). Effect of $\mathrm{pH}$ on growth and feeding parameters in Koi carp, Cyprinus carpio carpio var.koi. International Journal of Rsesarch Biological Science 4(1), 31-34.

Villaluz, A.C., \& A. Unggui. (1983). Effect of temperature on behavior, growth, development and survival in young milkfish, Channos channos (Forskal). Aquaculture, 35, 321-330. https://doi.org/10.1016/0044-8486(83)90104-7

Wang, Q., J. Liu. Z. Li., \& T. Zhang. (2015). Culturebased $f i$ sheries in lakes of the Yangtze River basin, China, with special reference to stocking of mandarin fish and Chinese mitten crab. In: Sena S. De Silva, B.A. Ingram and S. Wilkinson (eds.), Perspectives on culture-based $f i$ sheries developments in Asia, Bangkok, Thailand: Network of Aquaculture Centres in Asia-Pacific. (pp. 99-110).

Warsa, A., \& K. Purnomo. (2011). Potensi produksi dan status perikanan di Waduk Malahayu, Kabupaten Brebes-Jawa Tengah. Jurnal Penelitian Perikanan Indonesia, 17(4), 229- 237. DOI: http://dx.doi.org/10.15578/jppi.17.4.2011. 237-245

Warsa, A., J. Hariyadi, \& L.P. Astuti. (2018). Mitigasi beban fosfor dari kegiatan budidaya dengan penebaran ikan bandeng (Chanos chanos) di Waduk Cirata, Jawa Barat. Jurnal Teknologi Lingkunga, 19(2),259-266. DOI: 10.29122/jtl.v19i2.2669 
Jurnal Sumber Daya Air Vol. 15 No.2, November 2019: 95 - 106

Welcomme, R.L., \& D.M. Bartley. (1998). Current approach to the enhamcement of fisheries. Fisheries Managament 5, 351-382. https://doi.org/10.1046/j.13652400.1998.550351.x

Wijeyaratne, M.J.S., \& U.S. Amarasinghe. (1984). Estimation of maximum sustainable fish yield and stocking density of Inland Reservoir of Sri Lanka. J. NARA, 31, 65-72.
Wijenayake, W.M.H.K., U.A.D. Jayasinghe., U.S. Amarasinghe., J.A. Athula, K.C.B. Pushpalatha. \& S.S. De Silva. (2005). Culture-based fisheries in non-perennial reservoirs in Sri Lanka: production and relative performance of stocked species. Fisheries Management and Ecology 12, 249-258. DOI: $10.1111 /$ j.1365-2400.2005.00447.x 